CASE REPORT

\title{
Salmonella osteomyelitis of the distal radius in a healthy young adult patient : Report of a rare case and literature review
}

\author{
Ichiro Tonogai ${ }^{1,2}$, Yoshitaka Hamada ${ }^{3}$, Naohito Hibino², Ryosuke Sato ${ }^{1}$, Tatsuhiko Henmi ${ }^{2}$, and Koichi Sairyo ${ }^{1}$ \\ ${ }^{1}$ Department of Orthopedics, Institute of Health Biosciences, University of Tokushima Graduate School, Tokushima, Japan, ${ }^{2}$ Department of \\ Orthopedics, Tokushima Prefecture Naruto Hospital, Tokushima, Japan, ${ }^{3}$ Department of Orthopedics, Tokushima Prefectural Central Hospital \\ Tokushima, Japan
}

\begin{abstract}
Salmonella osteomyelitis of the radius in a healthy individual is very rare. We present such a case involving the distal radius of a healthy 23 -year-old man without underlying disease or possible episode. He had right wrist pain for approximately 3 years, and osteolytic lesion was seen in the right distal radius. He underwent surgical treatment, and salmonella was isolated from pus in the lesion. Postoperative antibiotics successfully treated his infection. He had no sign of recurrence, but the point of entry for infection remains unknown. J. Med. Invest. 62 : 97-99, February, 2015
\end{abstract}

Keywords : salmonella, osteomyelitis, radius

\section{INTRODUCTION}

Salmonella osteomyelitis is very rare, constituting $0.8 \%$ of all cases of salmonella infection and only $0.45 \%$ of all cases of osteomyelitis $(1,2)$. It is associated with sickle cell anemia and other hemoglobinopathies, immunosuppression, and the chronic salmonella carrier state $(3,4)$, but is very uncommon in healthy adults (5-9) and involving the radius. We report here a rare case of salmonella osteomyelitis in the distal radius of a healthy man without gastrointestinal symptoms or past history of disease following successful surgical treatment and antibiotics.

\section{CASE REPORT}

A healthy 23-year-old man presented with a complaint of recent worsening of pain in his right wrist over the preceding 2 weeks, though he had been suffering from dull pain in that wrist for 3 years. He was referred to the Tokushima Prefecture Naruto Hospital.

Upon presentation, there was no history of trauma, foreign travel, preceding diarrheal illness, or contact with reptiles. He was in good general condition and showed no signs of immunosuppression. His temperature was normal, and physical examination revealed tenderness and slight swelling on the dorsoradial side of the right wrist without of limitation of range of motion. Laboratory studies showed no leukocytosis (white cell count $4.4 \times 10^{9} / 1$ ) but showed a slightly elevated C-reactive protein level $(0.24 \mathrm{mg} / \mathrm{dl})$, and other blood chemistry was within normal limits. Radiography and computed tomography showed a rounded osteolytic lesion in the right distal radius from the epiphysis to the metaphysis (Fig. 1a, 1b). Magnetic resonance imaging revealed a low-intensity area on T1weighted images and a high-intensity area on T2-weighted images in the right distal radius, and the rim was enhanced after gadolinium injection (Fig. 1c).

We diagnosed osteomyelitis of the right distal radius and performed debridement and curettage. As the lesion was opened, a bony cavity was found, filled with turbid yellow fluid (Fig. 2a). The cavity was irrigated and the wall curetted. The cavity was filled with synthetic bone graft (Fig. 2b).

Postoperatively, salmonella was cultured from the pus. On further

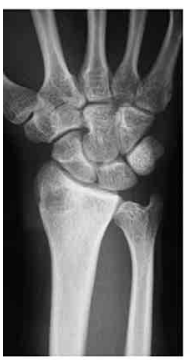

(a)

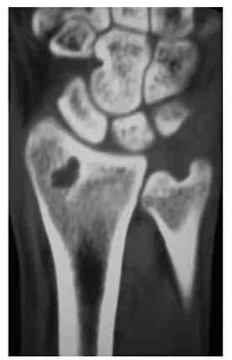

(b)

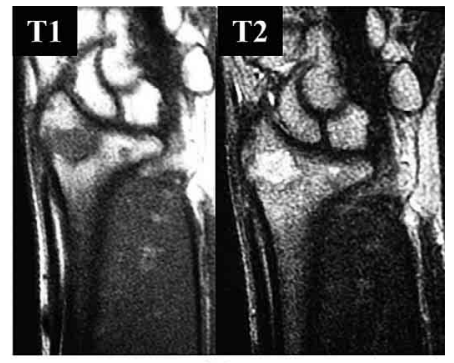

(c)

Figure 1: (a) Radiograph showing radioluency in the right distal radius. (b) Computed tomography image showing osteolytic change in the distal radius. (c) Magnetic resonance image showing the lesion of the right distal radius as low intensity on T1-weighted images and highintensity on T2-weighted images, with post-gadolinium rim enhancement.

Received for publication November 21, 2014 ; accepted December 24, 2014.

Address correspondence and reprint requests to Koichi Sairyo, MD, $\mathrm{PhD}$, Department of Orthopedics, Institute of Health Biosciences, University of Tokushima Graduate School, 3-18-15 Kuramoto, Tokushima 770-8503, Japan and Fax : +81-88-633-0178. 


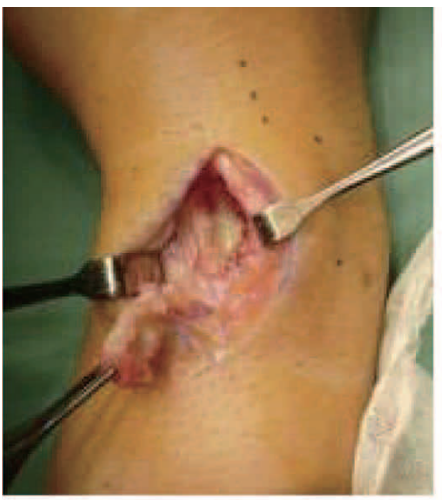

(a)

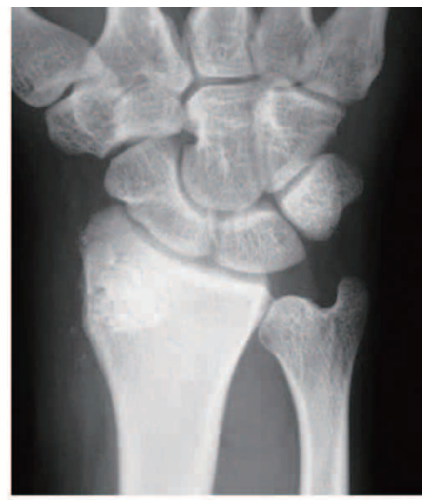

(b)

Figure 2: (a) The cavity of the right distal radius filled with purulent yellow fluid. (b) The cavity of the right distal packed with synthetic bone graft.

screening, a sickle test showed normal hemoglobin and he had negative blood, urine, and stool cultures. Initially, we administered intravenous cefotiam and intramuscular isepamicin, which were antibiotics with wide spectrum, to the patient. Then, as a specimen sample grown from the patient's pus was sensitive to $3^{\text {rd }}$ generation ephalosporins including flomoxef, and penicillin antibiotics including piperacillin and sultamicillin, it was decided that a 5 -day course of intravenous flomoxef and a further 7-day course of intravenous piperacillin followed by a further 20-day of oral sultamicillin.

The patient had an uneventful recovery, and his C-reactive protein level normalized postoperatively. Progressive healing of the lesion and integration of the synthetic bone graft were evident on follow-up radiographs. Two years after surgery, the patient is symptom free and has had no signs of recurrence.

\section{DISCUSSION}

The clinical manifestations of salmonella infection can be divided into five syndromes : enterocolitis (food poisoning), enteric (typhoid) fever, bacteremia/septicemia, focal infection, and a chronic carrier state $(7,8)$. The routes of infection include contaminated water, food such as eggs or poultry, and contact with reptiles (1014). Salmonella osteomyelitis occurs most frequently in patients with sickle cell diseases, and other risk factors include other hemoglobinopathies, immune deficiencies, and the chronic salmonella carrier state $(3,4)$. In the present case, the point of entry for infection remains unknown.

There are very few reports in the English literature of salmonella osteomyelitis in healthy individuals (5-9). Moreover, the radius is involved less often, with the long bones of the tibia, femur, humerus, and vertebrae most commonly involved $(15,16)$. To our knowledge, there are only three English-language case reports of salmonella osteomyelitis of the radius in healthy patients without predisposing disease (Table 1) (16-18).

After obtaining a bacteriological result from a sample, we administered flomoxef which belonged to $3^{\text {rd }}$ generation ephalosporins, and piperacillin and sultamicillin which belonged to penicillin

Table 1: Main features of salmonella osteomyelitis of the radius in immunocompetent patients without preceeding or underlying disease.

\begin{tabular}{|c|c|c|c|c|c|c|c|c|}
\hline References & $\begin{array}{l}\text { Age } \\
\text { (years) }\end{array}$ & Sex & $\begin{array}{c}\text { Site of } \\
\text { involvement }\end{array}$ & Presentation & Operation & Antibiotics & $\begin{array}{l}\text { Follow-up } \\
\text { (years) }\end{array}$ & Outcome \\
\hline $\begin{array}{l}\text { Adeyokunnu AA et al. } \\
1980\end{array}$ & 10 & Male & Right radius & N/A & None & $\begin{array}{l}\text { Chloramphenicol } \\
\text { and other antibiotics }\end{array}$ & N/A & Recovery \\
\hline $\begin{array}{c}\text { Declercq J et al. } \\
1994\end{array}$ & 41 & Male & $\begin{array}{l}\text { Epiphysis-diaphysis } \\
\text { of the left distal radius }\end{array}$ & $\begin{array}{l}\text { Pain (4 years) and } \\
\text { swelling (preceding } 1 \\
\text { week) of the left wrist }\end{array}$ & Irrigation & $\begin{array}{l}1 \text { day ciprofloxacin } \\
\text { and gentamicin } \\
15 \text { weeks ofloxacin }\end{array}$ & $\mathrm{N} / \mathrm{A}$ & N/A \\
\hline $\begin{array}{c}\text { Gaujoux-Viala C et al. } \\
2011\end{array}$ & 21 & Male & Radius & $\begin{array}{c}\text { Pain } \\
\text { (at least } 3 \text { years) }\end{array}$ & $\begin{array}{l}\text { Debridement } \\
\text { and curettage }\end{array}$ & $\begin{array}{l}1 \text { week gentamicin } \\
6 \text { weeks ceftriaxoue } \\
12 \text { weeks pefloxacin }\end{array}$ & 1 & Recovery \\
\hline $\begin{array}{c}\text { This case } \\
2014\end{array}$ & 23 & Male & $\begin{array}{l}\text { Epiphysis-metaphysis } \\
\text { of the right distal radius }\end{array}$ & $\begin{array}{l}\text { Pain in the right wrist } \\
\text { (3 years) }\end{array}$ & $\begin{array}{l}\text { Debridement } \\
\text { and curettage }\end{array}$ & $\begin{array}{l}3 \text { days cefotiam } \\
\text { and isepamicin } \\
5 \text { days flomoxef } \\
7 \text { days piperacillin } \\
3 \text { weeks sultamicillin }\end{array}$ & 2 & Recovery \\
\hline
\end{tabular}


antibiotics to the patients, because $3^{\text {rd }}$ generation ephalosporins and penicillin antibiotics like ampicillin had been used successfully in salmonella osteomyelitis $(1,19)$. These antibiotics were useful for salmonella osteomyelitis in our case. The total duration of antibiotic administration in our case was shorter than in the other 2 cases that have been documented, as Table 1 shows, but optimal duration of treatment with antibiotics for salmonella osteomyelitis is still unknown (20). This duration may be based on the resolving clinical signs and symptoms as well as the inflammatory markers returning to normal levels.

On the other hand, salmonella osteomyelitis is refractory and tends to be chronic, relapsing, and difficult to eradicate (21-23). Extensive and often multiple debridements are required (19). Tanigushi et al. even reported a case that was treated with a free vascularized fibula graft (21). Fortunately, our patient has had no recurrence 2 years after the operation. We will continue to follow the patient periodically as late recurrent osteomyelitis may occur years after symptom-free periods.

\section{CONFLICT OF INTERESTS}

The authors declare that there is no conflict of interests regarding the publication.

\section{REFERENCES}

1. Sanchez AA, Mazurek MT, Clapper MF : Salmonella osteomyelitis presenting as fibrous dysplasia. A case report. Clin Orthop Relat Res 330 : 185-189, 1996

2. Ingram R, Redding $\mathrm{P}$ : Salmonella virchow osteomyelitis. A case report. J Bone Joint Surg Br 70(3) : 440-442, 1988

3. Hook EW, Campbell CG, Weens HS, Cooper GR: Salmonella osteomyelitis in patients with sickle-cell anemia. N Engl J Med 257(9) : 403-407, 1957

4. Engh CA, Hughes JL, Abrams RC, Bowerman JW : Osteomyelitis in the patient with sickle-cell disease. J Bone Joint Surg Am 53(1) : 1-15, 1971

5. Monsivais JJ, Scully TJ, Dixon BL : Chronic osteomyelitis of the hand caused by Salmonella typhimurium. A case report. Clin Orthop Relat Res 226 : 231-234, 1988

6. Cobos JA, Calhoun JH, Mader JT : Salmonella typhi osteomyelitis in a nonsickle cell patient. A case report. Clin Orthop Relat Res 288 : 277-281, 1993

7. van Cappelle HG, Veenendaal D, de Vogel PL: Salmonella panama osteomyelitis in an otherwise healthy patient. A case report. Clin Orthop Relat Res 321 : 235-238, 1995

8. Spencer J, Cattermole G, Andrade T, Dryden M, Fowler J : Salmonella osteoarticular infection without predisposing factors. J R Soc Med 92(7) : 363-364, 1999

9. Salem $\mathrm{KH}$ : Salmonella osteomyelitis : A rare differential diagnosis in osteolytic lesions around the knee. J Infect Public Health 7(1) : 66-69, 2014

10. Kraus A, Guerra-Bautista G, Alarcón-Segovia D : Salmonella arizona arthritis and septicemia associated with rattlesnake ingestion by patients with connective tissue diseases. A dangerous complication of folk medicine. J Rheumatol 18(9) : 1328-1331, 1991

11. Nowinski RJ, Albert MC : Salmonella osteomyelitis secondary to iguana exposure. Clin Orthop Relat Res 372:250-253, 2000

12. Bello CS, Singh S, Al-Waley A, Hyde M, Khan MR: Salmonella arizonae infection from snake bite. Ann Saudi Med 21 (5-6) : 352-353, 2001

13. Warwick C, Lambiris AJ, Westwood D, Steedman C : Reptilerelated salmonellosis. J R Soc Med 94(3) : 124-126, 2001

14. Linam WM, Gerber MA : Changing epidemiology and prevention of Salmonella infections. Pediatr Infect Dis J 26(8) : 747748,2007

15. Ortiz-Neu C, Marr JS, Cherubin CE, Neu HC : Bone and joint infections due to Salmonella. J Infect Dis 138(6) : 820-828, 1978

16. Declercq J, Verhaegen J, Verbist L, Lammens J, Stuyck J, Fabry G : Salmonella typhi osteomyelitis. Arch Orthop Trauma Surg 113(4) : 232-234, 1994

17. Adeyokunnu AA, Hendrickse RG : Salmonella osteomyelitis in childhood. A report of 63 cases seen in Nigerian children of whom 57 had sickle cell anaemia. Arch Dis Child 55(3) : 175-184, 1980

18. Gaujoux-Viala C, Zeller V, Leclerc P, Chicheportiche V, Mamoudy P, Desplaces N, Ziza JM : Osteomyelitis in adults : an underrecognized clinical entity in immunocompetent hosts. A report of six cases. Joint Bone Spine 78(1) : 75-79, 2011

19. Bettin D, Schaphorn G, Blasius S, Becker K, Niemeyer T : A rare case of Salmonella osteomyelitis in the humerus as a differential diagnosis to a malignant bone tumor. Arch Orthop Trauma Surg 122(9-10) : 544-546, 2002

20. Banky JP, Ostergaard L, Spelman D : Chronic relapsing salmonella osteomyelitis in an immunocompetent patient: case report and literature review. J Infect 44(1) : 44-47, 2002

21. Taniguchi $Y$, Nomura K, Tamaki $T$ : Free vascularized fibular graft in the treatment of Salmonella typhi osteomyelitis of the distal radius. J Reconstr Microsurg 14(1) : 13-16, 1998

22. Lang R, Maayan MC, Lidor C, Savin H, Kolman S, Lishner M : Salmonella paratyphi C osteomyelitis : report of two separate episodes 17 years apart. Scand J Infect Dis 24(6) : 793-796, 1992

23. Rayan F, Mukundan C, Shukla DD : A case of relapsing Salmonella osteomyelitis in a thalassaemia trait patient. J Orthop Traumatol 10(1) : 31-33, 2009 